\title{
Исследование однофотонной излучающей системы на основе NV-центров в наноалмазах, интегрированных с НHК GaP
}

\author{
А.С. Голтаев ${ }^{1}$, А.М. Можаров ${ }^{1}$, В.В. Ярошенко ${ }^{2}$, Д.А. Зуев ${ }^{2}$, И.С. Мухин ${ }^{1}$ \\ ${ }^{1}$ Академический университет им. Ж.И. Алфёрова, Санкт-Петербург, \\ 194021, улича Хлопина, дом 8, корпус 3, литер А \\ ${ }^{2}$ ИТМО, Санкт-Петербург, 197101, г. Санкт-Петербург, Кронверкский проспект, д. 49 \\ тел:+7 (953) 457-7123, факс:+7 (812) 297-21-45, эл. почта: AKBAPNYM@yandex.ru
}

DOI 10.34077/RCSP2021-57

Наноразмерные квантово-оптические излучатели являются основными элементами квантовой оптики и зондирования. В качестве таких источников можно использовать наноалмазы (НА) с оптически активными точечными дефектами в кристаллической решетке. Одним из наиболее изученных и полезных дефектов является азотнозамещенная вакансия или NV-центр. Спинами электронов в NV-центрах можно манипулировать при комнатной температуре с помощью магнитного поля, электрического поля или оптического излучения [1]. Основная проблема, ограничивающая применение NV-центров в квантовых нанофотонных системах, связана с низкой яркостью бесфононной линии (БФЛ) при комнатной температуре из-за широкой фононной боковой полосы [2]. Традиционный подход к проблеме увеличения скорости излучения NV-центра, а также эффективного сбора испускаемых фотонов предполагает объединение излучающих наноалмазов с оптическими нанорезонаторами или волноводами. Нитевидные нанокристаллы (НHК) из фосфида галлия (GaP) могут использоваться в качестве оптических резонансных систем, поскольку ННК GaP имеет узкую запрещенную зону и прозрачен для видимого диапазона, что идеально подходит для NV-центров [3]. Другим преимуществом является показатель преломления, который составляет около 3,2 в видимом диапазоне, что выше, чем у большинства оптических материалов, например, показатель преломления алмаза составляет 2,4 .

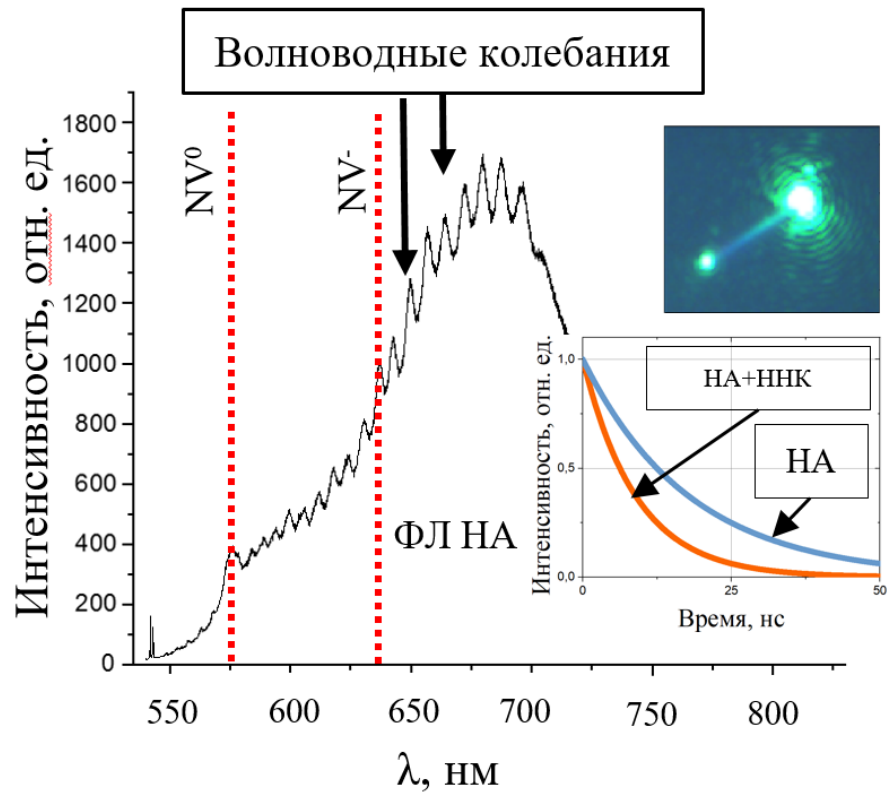

Рис. 1 - Спектр ФЛ одиночного ННК с НА; на вставках: эффект улавливания света ННК; кривые затухания люминесценции для НА+ННК и референсного образца (НА)
Эпитаксиальные массивы GaP НHК были синтезированы на подложке $\mathrm{Si}$ (111) на установке PA-MBE Veeco GEN-III. Морфология синтезированных $\mathrm{GaP}$ НHК изучалась с помощью сканирующего электронного микроскопа (СЭM) (Zeiss SUPRA 25-30-63).

Микроспектроскопические исследования отклика ФЛ и комбинационного рассеяния света (КРС) отдельных ННК и ансамбля НА были выполнены при 300 К для изучения химического состава и модуляции ФЛ собственными модами резонатора. Время жизни фотонов было получено с использованием метода TCSPC (рис. 1).

B данной работе разработан технологический процесс интеграции источников однофотонного излучения в резонансную систему ННК из фосфида галлия. Проанализированы оптические свойства изготовленной структуры и получены спектры ФЛ и КРС. Зависимость скорости спонтанного излучения исследовалась для системы НА, совмещенных с одиночными НHК GaP, а также для HA, осажденных на стеклянную подложку, в качестве референсного образца. Данные показали увеличение скорости спонтанного излучения при интегрировании наноалмазов с GaP ННК.

\section{Лumepamypa}

[1] P. C.Maurer et. al. // Nature Phys. 2010. 6(11) 912-918.

[2] I. Aharonovich et. al. // Rep. Prog. Phys. 2011. 74(7) 076501.

[3] D. Verardo et. al. // Nano Lett. 2018. 18(8) 4796-4802. 